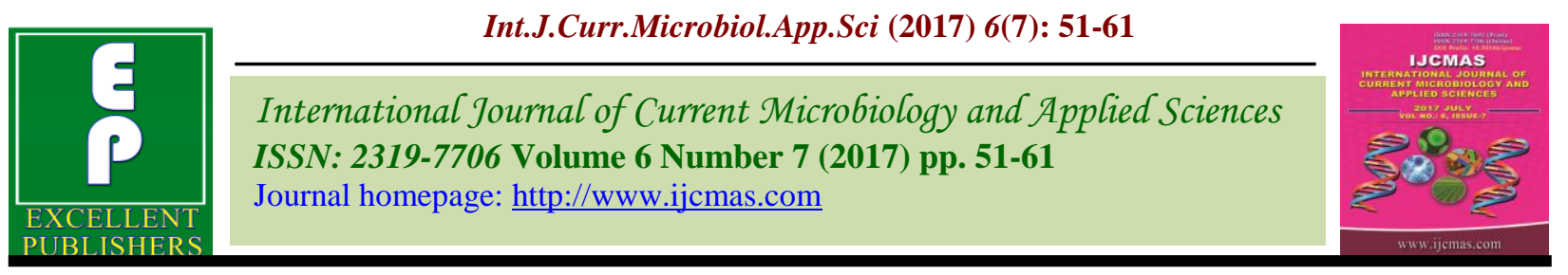

Original Research Article

https://doi.org/10.20546/ijcmas.2017.607.007

\title{
GC-MS Analysis of Phyto-Components in Raw and Treated Sugarcane Juice
}

\author{
P. Rajendran ${ }^{1 *}$, R. Bharathidasan ${ }^{1}$ and K. Sureshkumar ${ }^{2}$ \\ ${ }^{1}$ Department of Microbiology, Maruthupandiyar College, Thanjavur-613403, Tamil Nadu, India \\ ${ }^{2}$ Department of Food Biotechnology, Indian Institute of Food Processing Technology, Ministry \\ of Food Processing Industries, Thanjavur,613 005, Tamil Nadu, India \\ *Corresponding author
}

\begin{tabular}{|l|}
\hline K e y w o r d s \\
$\begin{array}{l}\text { Saccharum } \\
\text { officinarum, } \\
\text { Natural } \\
\text { preservatives, } \\
\text { GC-MS, Phyto- } \\
\text { component. }\end{array}$ \\
\hline Article Info \\
\hline $\begin{array}{l}\text { Accepted: } \\
\text { 04 June } 2017 \\
\text { Available Online: } \\
\text { 10 July } 2017\end{array}$ \\
\hline
\end{tabular}

\section{A B S T R A C T}

Sugarcane (Saccharum officinarum) is the major cash crop of the Indian tropical and subtropical region. Mostly, the foremost part of Indian economy is based on sugarcane crop, which is cultivated in major state of India. Phyto-components are the compound that occurred in plant naturally and play important role for biologically activity (antibacterial, anti-fungal, anti-cancer, anti-diabetic etc.), to prevent many diseases by scavenging and chelating the free radicals. Preservation of sugarcane juice was examined to reduce the spoilage and to increase the shelf life using natural preservatives. The preservation of the juice was carried out using ginger, neem, mint and black salt and stored under refrigeration temperature. In the present study, we identified the phyto-components presence in raw sugarcane juice and addition of additives such as ginger, lemon, mint and black salt of sugarcane juice through GC-MS analysis. In the raw sugarcane juice, it was identified that the major compound 5-Hydroxymethylfurfural (39.56\%) with retention time 12.99 min and the minor compound was Isopropyl linoleate $(0.88 \%)$ with 30.80 retention time. When compared to raw sugarcane juice, treated sugarcane juice has 9,12 , 15- Octadecatrienoic acid, 2,3-bis[(trimethylsilyl)oxy]propyl ester, $\quad(\mathrm{Z}, \mathrm{Z}, \mathrm{Z}) \quad(6.29 \%), \quad 8 \mathrm{H}-\mathrm{Pyrano}$ [3,4b]pyrimido[5,4-d]furane, 5,6-dihydro-4-hydrazino-6,6-dimethyl-2-methylthio(6.01\%), Ethanone, 1-(1a,2,3,5,6a,6b-hexahydro-3,3,6a-trimethyloxireno[g]benzofuran-5yl)(1.43\%), with retention time $36.60,22.58$ and 23.48 mins respectively. Significant compounds such as 1,8-Dioxa-5-thiaoctane, 8-(9-borabicyclo[3.3.1]non-9-yl)-3-(9borabicyclo[3.3.1]non-9-yloxy)-1-phenyl- (0.16\%) and Androstane-11,17-dione, 3[(trimethylsilyl)oxy]-, 17-[O-(phenylmethyl)oxime], $(3 \alpha, 5 \alpha)$ - $(0.17 \%)$ were also identified. the identified compounds having biological and pharmacological activity such as antimicrobial, antifungal, anticancer, antioxidant, antimutagenic and hypercholesterolemic properties. Hence the developed hurdle technology can be adopted to extend the shelf life of sugarcane juice.

\section{Introduction}

Sugarcane (Saccharum officinarum) is an important industrial crop cultivated in tropical and subtropical regions of the world. India is the world second largest producer of sugarcane next to Brazil. Sugarcane has been used as a sweetener for millennia and today refined sugar is used in copious quantities to supplement the natural sugar (fructose) found in fruits and vegetables (Phanikumar, 2011). Sugarcane juice is commonly used as a delicious drink in both urban and rural areas. A part of sugarcane juice consumed as expensive and pleasing beverages in India. It possesses therapeutic value (Banerji et al., 1997). 
In general sugarcane juice is spoiled quickly by the presence of simple sugars. The sugarcane juice can be introduced as delicious beverages by preventing the spoilage of juice with appropriate method. Biodegradation is caused by microorganisms mainly Leuconostoc sp. (L. mesenteroides and $L$. dextranium) also takes place (Krishnakumar and Devadas, 2006).

Many commercial juices are filtered to remove fiber or pulp, but high-pulp fresh orange juice is a popular beverage. Common methods for preservation and processing of fruit juices include canning, pasteurization, freezing, evaporation, drying and addition of preservatives (Ashish Khare et al., 2012).

According to research reports, phytocompounds are proven to have important biological and medicinal properties that may make sugarcane a valuable functional food plant (Iacopini et al., 2008). Additionally, the use of $S$. officinarum in traditional medicine in Nigeria and some parts of Asia especially India for the treatment of diseases such as jaundice and liver-related disorders, dyspepsia, haemorrhoids, menorrhagia, dysentery, agalactia, phthisis and general debility (Kadam et al., 2008; Suresh-Kumar et al., 2010) suggest inherent medicinal phytochemicals.

The role of phyto-components in protecting tissues and cells against destructive effects of free radical has been greatly studied. The market in India for antioxidant rich supplements, fortified drinks and snacks has now advanced well into the mainstream, with products like green tea, antioxidant enriched drinks, health bars, powder drink mixes, etc. The by-product of sugarcane industry, blackstrap molasses, has been recognized for its therapeutic properties. Considering, these aspects it becomes worthwhile to have a deeper insight for antioxidant properties of sugarcane (Manish et al., 2015).
Gas Chromatography (GC) and mass spectrometry (MS) provides a powerful tool for identifying the various compound presences in the sample. GC separate mixture in to individual components and the MS detects components or molecules on the basis of their charged ion and mass to charge ratio. The objective of the present study was to GCMS analysis of juice sample from the selected plant for the identification of phytocomponents and their relation to biological and pharmacological activity.

Therefore, the study evaluated the phytocomponents of raw sugarcane juice and treated sugarcane juice as well as its antimicrobial properties. Data generated from such studies as this, will contribute to the phyto-components database useful in the assessment of antimicrobial properties, a major prerequisite for solving the problem of food spoilage in developing countries including India. The study will also serve to provide some baseline data necessary for further investigation into the functional properties of sugarcane juice.

\section{Materials and Methods}

\section{Collection of plant material}

Mature stems of sugarcane were cut close to the ground at a plantation in Thanjavur during the period of July, 2015. Upon arrival at the laboratory, the stems were cleaned, handpeeled and cut into three portions with equal length (about $50 \mathrm{~cm}$ ) and used for the experiment.

\section{Preparation and formulation of sugarcane juice}

Sugarcane juice was extracted by power operated sugarcane crusher machine. The collected sugarcane juice was filtered through the double sieve and muslin cloth to remove 
the extraneous matter. The sugarcane juice was brought to the laboratory for further processing. The process flow chart for sugarcane juice recovery is given in Figure 2. With $100 \mathrm{ml}$ of sugarcane juice, $0.6 \mathrm{ml}$ the ginger extract, 1.5 lemon extract, $0.5 \mathrm{ml}$ of mint extract and $1 \mathrm{gm}$ of black salt were added. Without these additives raw sugarcane juice (RSJ) act as control and addition of additives was designated as treated sugarcane juice (TSJ) respectively.

\section{GC-MS analysis of the sample}

The chemical composition of sugarcane juice with and without treatment was investigated through Gas Chromatography Mass Spectrometry with Electron Ionization (GC$\mathrm{MS} / \mathrm{EI}$ ) mode. Around $50 \mathrm{ml}$ sugarcane juice was soaked in 1:2 ratio of hexane and incubated at shaking incubator overnight at room temperature and then filtered through blotting paper. The filtrate is then concentrated through nitrogen gas flushing up to $1 \mathrm{ml}$ through Sample Concentrator. The concentrate was again filtered in the Whatmann No. 41 filter paper along with Sodium sulfate to remove the sediments and traces of moisture in the filtrate. This procedure insures precise derivatization time and reproducible sample injection. Immediately after extraction and filtration, 2 $\mu l$ of the sample was injected into an injection port in 1:10 ratio of split mode. The mobile gas helium was set to $1 \mathrm{ml} \mathrm{min}^{-1}$.

The GC-MS/MS is a Scion 436-GC Bruker model coupled with a Triple quadruple mass spectrophotometer with fused silica capillary column BR-5MS (5\% Diphenyl/ 95\% Dimethyl poly siloxane) and Length : 30m; Internal diameter: $0.25 \mathrm{~mm}$; Thickness: $0.25 \mu \mathrm{m}$. The column oven temperature program was as follows: $40^{\circ} \mathrm{C}$ hold for $2 \mathrm{~min}$, $\mathrm{Up}$ to $160^{\circ} \mathrm{C}$ at the rate of $20^{\circ} \mathrm{C} / \mathrm{min}-\mathrm{No}$ hold, Up to $280^{\circ} \mathrm{C}$ at the rate of $5^{\circ} \mathrm{C} / \mathrm{min}$ -
No hold, Up to $300^{\circ} \mathrm{C}$ at the rate of $12^{\circ} \mathrm{C} / \mathrm{min}$ - 8 min hold, Injector temperature $280^{\circ} \mathrm{C}$ and total GC running time was $41 \mathrm{~min}$. This last increase was to clean the column from any residues. The mass spectrometer was operated in the positive electron ionization (EI) mode with ionization energy of $70 \mathrm{eV}$. The solvent delay was 0-3.0 min.

A scan interval of 0.5 seconds and fragments from $\mathrm{m} / \mathrm{z} 50$ to 500 kilo Daltons was programmed. The inlet temperature was set at $280^{\circ} \mathrm{C}$, source temperature $250^{\circ} \mathrm{C}$. The relative percentage amount of each component was calculated by comparing its average peak area to the total areas. Software adopted to handle mass spectra and chromatograms was MS Work station 8. The NIST Version 2.0 library database of National Institute Standard and Technology (NIST) having more than 2, 42,466 patterns were used for identifying the chemical components. The spectrum of the unknown component was compared with the spectrum of the known components stored in the NIST library. The name, molecular weight and structure of the components of the test materials were ascertained.

\section{Results and Discussion}

\section{GC-MS analysis of raw sugarcane juice}

GC-MS analysis of n- hexane juice extract obtained from raw sugarcane juice (Saccharum officinarum) revealed the presence of 14 phytochemical compounds as depicted by 14 respective peaks for each compound in GC-MS chromatogram (Table 2 and Fig. 1). Major compounds identified were 5-Hydroxymethylfurfural $\quad(39.56 \%)$ and Cyclopropyl 4-methoxyphenyl ketone (19.58\%) with retention time 12.99 and 8.30 min respectively. Minor compounds such as Isopropyl linoleate $(0.88 \%)$ and Pentanal, 5(methylenecyclopropyl) (2.99\%) with 
retention time 30.80 and $10.99 \mathrm{~min}$ respectively were identified.

\section{GC-MS analysis of treated sugarcane juice}

GC-MS analysis of $\mathrm{n}$ - hexane juice extract obtained from treated sugarcane juice (Saccharum officinarum)with addition of additives revealed the presence of 19 phytochemical compounds as depicted by 19 respective peaks for each compound in GCMS chromatogram (Table 3, Fig. 3). major compounds were identified 9, 12, 15Octadecatrienoic acid, 2,3bis[(trimethylsilyl)oxy]propyl ester, (Z,Z,Z) (6.29\%), 8H-Pyrano[3,4-b] pyrimido [5,4-d] furane, 5,6-dihydro-4-hydrazino-6, 6dimethyl-2-methylthio $(6.01 \%)$, Ethanone, 1-(1a, 2,3,5,6a,6b-hexahydro3,3,6a-trimethyloxireno[g] benzo furan-5-yl) $(1.43 \%)$, with retention time $36.60,22.58$ and 23.48 respectively. Lower percentage compound were identified 1,8-Dioxa-5thiaoctane, 8-(9-borabicyclo [3.3.1] non-9yl)-3- (9-borabicyclo[3.3.1]non-9-yloxy)-1phenyl- $(0.16 \%)$ and Androstane-11,17-dione, 3-[(trimethylsilyl)oxy]-, $17-[\mathrm{O}-$ (phenylmethyl) oxime], $(3 \alpha, 5 \alpha)-(0.17 \%)$ with retention time 35.09 and 31.48 respectively.

The compounds present were of different classes such as steroids, acids, phytosterols, alkaloids, ketones, ester, etc. Among different compounds identified 9, 12, 15Octadecatrienoic acid, Octadecatrienoic acid, 2,3-bis[(trimethylsilyl)oxy]propyl ester, (Z,Z,Z) 8H-Pyrano[3,4-b] pyrimido [5,4-d] furane, 5,6-dihydro-4-hydrazino-6,6dimethyl-2-methylthio, Ethanone, 1(1a,2,3,5,6a,6b-hexahydro-3,3,6a-trimethyl oxireno[g]benzofuran-5-yl) were found to be present in large amount as when compared to phytocompounds of raw sugarcane juice based upon the peak areas of the compounds.

Irrespective of the amount or concentration (high or low) in which these compounds were found to be present, almost all these compounds have been reported to possess some pharmacological or the other biological activity (Table 1).

Kim et al., 2010 Syringol and 4hydroxydihydro-2(3H)-furanone are known to possess antioxidant activities. Many phytochemical compounds identified such as, Tridemorph, Pentanal, 2-methyl, 4H-Pyran-4one, 2, 3-, dihydro-3, 5-dihydroxy-6-methyl-, 4-hydroxydihydro-2(3H)-furanone, 2Furancarboxaldehyde, 5-(hydroxymethyl) have been reported to be antimicrobial (antibacterial or antifungal) in nature.

Fig.1 GC-MS chromatogram of raw sugarcane juice

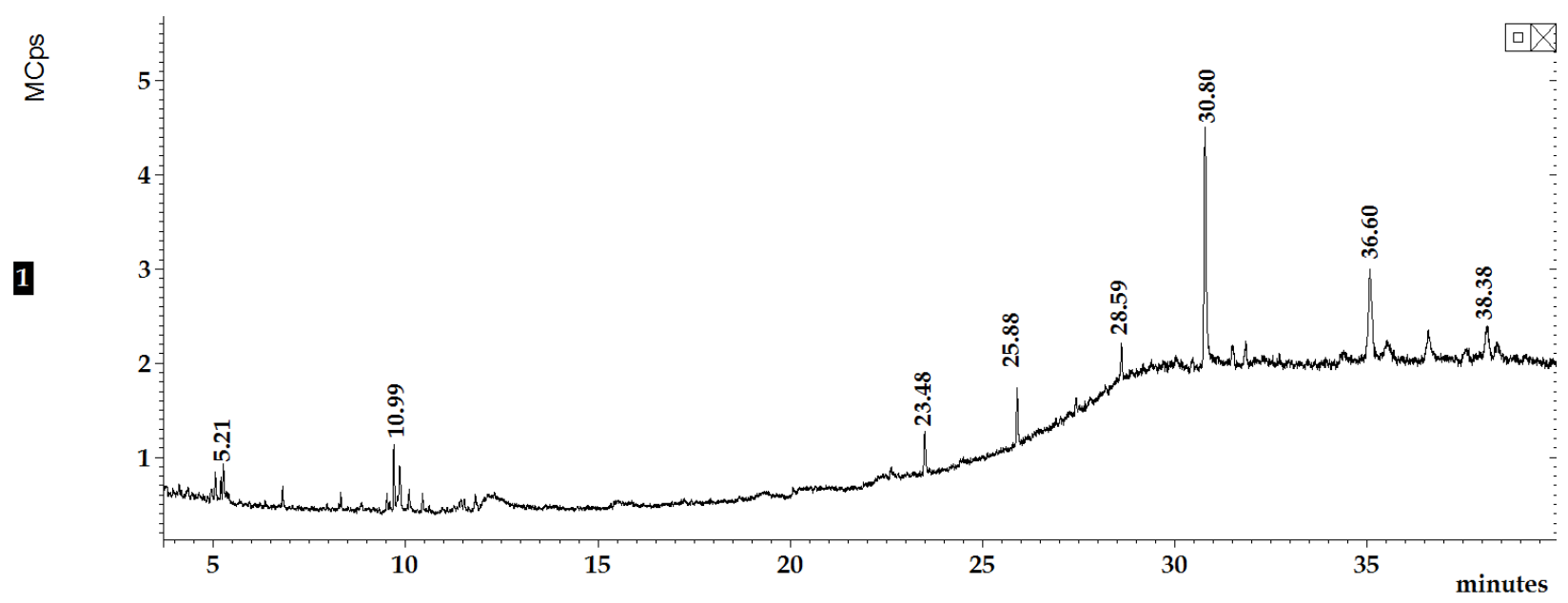


Fig.2 The process flow chart for raw sugarcane juice preparation

Fresh sugarcane stem

Washing, grading and peeling of sugarcane stem

Juice extraction by sugarcane crushing machine

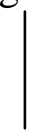

Filtration through double sieve

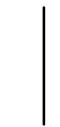

Cleared extract /juice of sugarcane

Fig.3 GC-MS Chromatogram of Treated Juice Sample

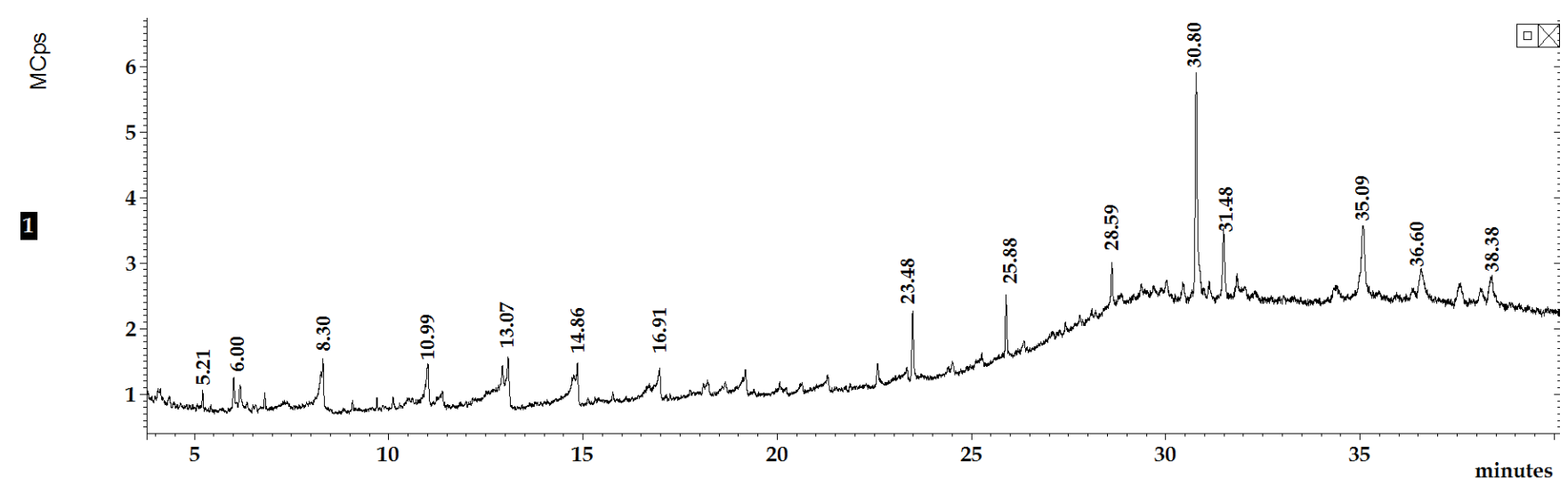

Table.1 Biological activity of identified compound in treated sugarcane juice

\begin{tabular}{|l|l|l|l|}
\hline S.No & Compound name & Structure & $\begin{array}{l}\text { Biological/Pharmacological } \\
\text { activities* }\end{array}$ \\
\hline 1. & Dodecane, 1,2-dibromo- & Antimicrobial Activity \\
\hline 2. & $\begin{array}{l}\text { 2-Cyclopentenone, 2- } \\
\text { acetyl-3-methylamino- }\end{array}$ & Anti-inflammatory \\
\hline
\end{tabular}




\begin{tabular}{|c|c|c|c|}
\hline 3. & tert-Hexadecanethiol & & Enzyme activators \\
\hline 4. & $\begin{array}{l}\text { Cyclopropyl 4- } \\
\text { methoxyphenyl ketone }\end{array}$ & & Antibacterial, Analgesic \\
\hline 5. & $\begin{array}{l}\text { Pentanal, } \\
\text { (methylenecyclopropyl)- }\end{array}$ & & \\
\hline 6. & $\begin{array}{l}\text { 5- } \\
\text { Hydroxymethylfurfural }\end{array}$ & & Antioxidant Activity \\
\hline 7. & Cyclobarbital & & $\begin{array}{l}\text { Antimicrobial and } \\
\text { Anticancerous }\end{array}$ \\
\hline 8. & $\begin{array}{l}\text { Butanoic acid, 3-oxo-, 2- } \\
\text { propenyl ester }\end{array}$ & & Antimicrobial Activity \\
\hline 9. & $\begin{array}{l}\text { Furan-2-carboxaldehyde, } \\
\text { 5-(1-piperidyl)- }\end{array}$ & & Antioxidant Activity \\
\hline 10. & $\begin{array}{l}\text { 8H-Pyrano[3,4- } \\
\text { b]pyrimido[5,4-d]furane, } \\
\text { 5,6-dihydro-4- } \\
\text { hydrazino-6,6-dimethyl- } \\
\text { 2-methylthio- }\end{array}$ & & Antitumor activity \\
\hline
\end{tabular}




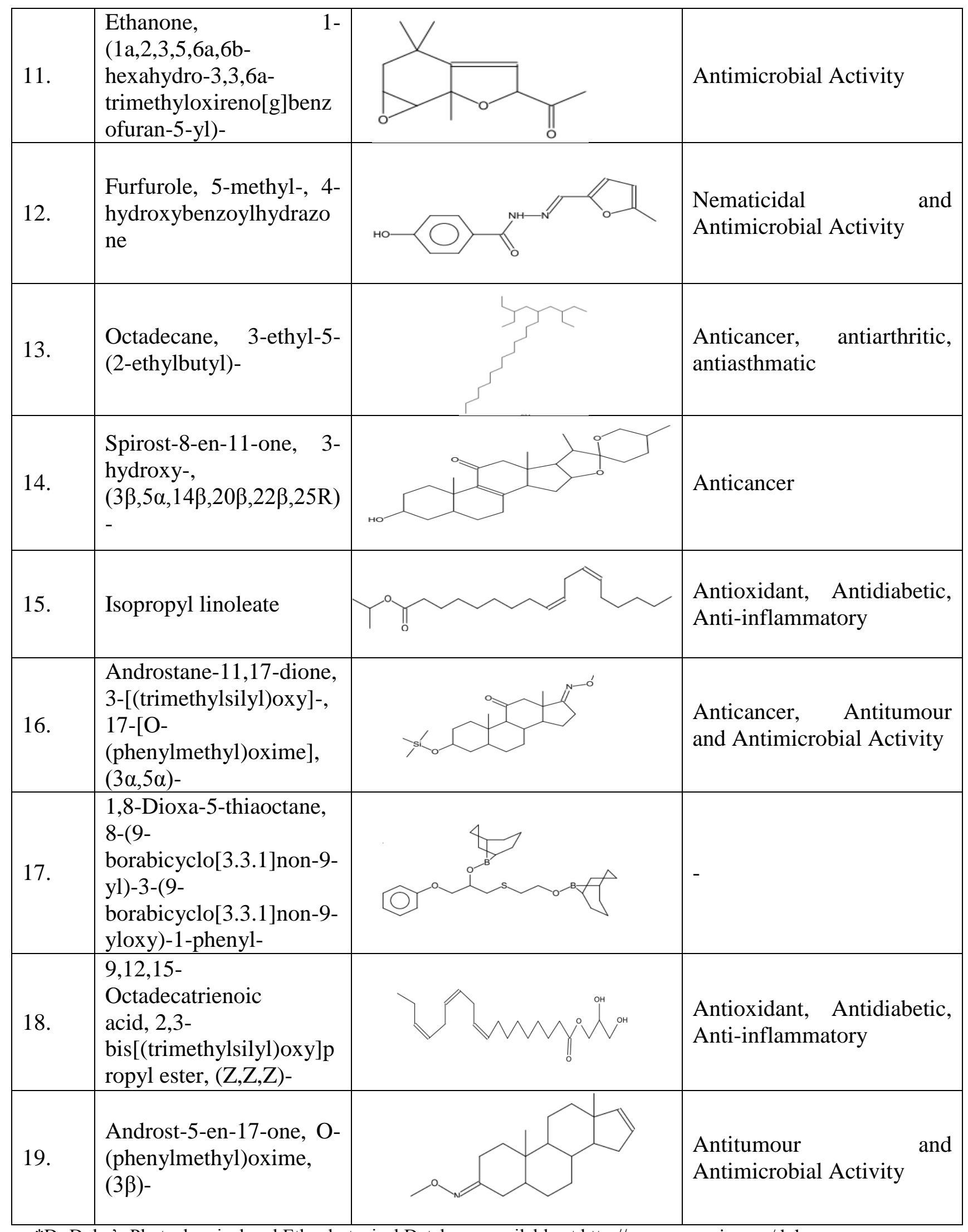

*Dr.Duke's Phytochemical and Ethnobotanical Databases available at http://www.ars-grin-gov/duke 
Table.2 Identified compound, area and retention time of peak of raw sugarcane juice

\begin{tabular}{|c|c|c|c|c|c|}
\hline $\begin{array}{l}\text { S. } \\
\text { No. }\end{array}$ & RT & Name of the compound & $\begin{array}{l}\text { Molecular } \\
\text { Formulae }\end{array}$ & $\begin{array}{l}\text { Molecula } \\
\text { r Weight }\end{array}$ & $\begin{array}{l}\text { Peak } \\
\text { Area } \%\end{array}$ \\
\hline 1. & 5.21 & Dodecane, 1,2-dibromo- & $\mathrm{C}_{12} \mathrm{H}_{24} \mathrm{Br}_{2}$ & 326 & 5.89 \\
\hline 2. & 6.80 & tert-Hexadecanethiol & $\mathrm{C}_{16} \mathrm{H}_{34} \mathrm{~S}$ & 258 & 4.18 \\
\hline 3. & 8.30 & Cyclopropyl 4-methoxyphenyl ketone & $\mathrm{C}_{11} \mathrm{H}_{12} \mathrm{O}_{2}$ & 176 & 19.58 \\
\hline 4. & 10.99 & Pentanal, 5-(methylenecyclopropyl)- & $\mathrm{C}_{9} \mathrm{H}_{14} \mathrm{O}$ & 138 & 2.99 \\
\hline 5. & 12.99 & 5-Hydroxymethylfurfural & $\mathrm{C}_{6} \mathrm{H}_{6} \mathrm{O}_{3}$ & 126 & 39.56 \\
\hline 6. & 14.86 & Cyclobarbital & $\mathrm{C}_{12} \mathrm{H}_{16} \mathrm{~N}_{2} \mathrm{O}_{3}$ & 236 & 5.63 \\
\hline 7. & 22.58 & $\begin{array}{l}\text { 8H-Pyrano[3,4-b]pyrimido[5,4-d]furane, } \\
\text { 5,6-dihydro-4-hydrazino-6,6-dimethyl-2- } \\
\text { methylthio- }\end{array}$ & $\mathrm{C}_{12} \mathrm{H}_{16} \mathrm{~N}_{4} \mathrm{O}_{2} \mathrm{~S}$ & 280 & 5.55 \\
\hline 8. & 23.48 & $\begin{array}{l}\text { Ethanone, 1-(1a,2,3,5,6a,6b-hexahydro- } \\
\text { 3,3,6a-trimethyloxireno[g]benzofuran-5- } \\
\text { yl)- }\end{array}$ & $\mathrm{C}_{13} \mathrm{H}_{18} \mathrm{O}_{3}$ & 222 & 6.52 \\
\hline 9. & 25.88 & Octadecane, 3-ethyl-5-(2-ethylbutyl)- & $\mathrm{C}_{26} \mathrm{H}_{54}$ & 366 & 3.25 \\
\hline 10. & 28.59 & $\begin{array}{l}\text { Spirost-8-en-11-one, } \\
(3 \beta, 5 \alpha, 14 \beta, 20 \beta, 22 \beta, 25 \mathrm{R})-\end{array}$ & $\mathrm{C}_{27} \mathrm{H}_{40} \mathrm{O}_{4}$ & 428 & 0.47 \\
\hline 11. & 30.80 & Isopropyl linoleate & $\mathrm{C}_{21} \mathrm{H}_{38} \mathrm{O}_{2}$ & 322 & 0.88 \\
\hline 12. & 31.48 & $\begin{array}{l}\text { Androstane-11,17-dione, } \\
\text { [(trimethylsilyl)oxy]-, } \\
\text { (phenylmethyl)oxime], }(3 \alpha, 5 \alpha)-\end{array}$ & $\mathrm{C}_{29} \mathrm{H}_{43} \mathrm{NO}_{3} \mathrm{Si}$ & 481 & 0.05 \\
\hline 13. & 36.60 & $\begin{array}{lr}9,12,15-\quad \text { Octadecatrienoic } & \text { acid, 2,3- } \\
\text { bis[(trimethylsilyl)oxy]propyl } & \text { ester, } \\
(\mathrm{Z}, \mathrm{Z}, \mathrm{Z})- & \end{array}$ & $\mathrm{C}_{27} \mathrm{H}_{52} \mathrm{O}_{4}$ & 496 & 4.56 \\
\hline 14. & 38.38 & $\begin{array}{l}\text { Androst-5-en-17-one, } \\
\text { (phenylmethyl)oxime, }(3 \beta)-\end{array}$ & $\mathrm{C}_{29} \mathrm{H}_{43} \mathrm{NO}_{2}$ & 465 & 0.89 \\
\hline
\end{tabular}


Table.3 Identified compound, area and retention time of peak of treated sugarcane juice

\begin{tabular}{|c|c|c|c|c|c|}
\hline No. & $\mathbf{R T}^{*}$ & Name of the compound & $\begin{array}{l}\text { Molecular } \\
\text { Formulae }\end{array}$ & $\begin{array}{l}\text { Molecular } \\
\text { Weight }\end{array}$ & $\begin{array}{l}\text { Peak } \\
\text { Area } \%\end{array}$ \\
\hline 1. & 5.21 & Dodecane, 1,2-dibromo- & $\mathrm{C}_{12} \mathrm{H}_{24} \mathrm{Br}_{2}$ & 326 & 6.36 \\
\hline 2. & 6.00 & $\begin{array}{l}\text { 2-Cyclopentenone, } \\
\text { methylamino- }\end{array}$ & $\mathrm{C}_{8} \mathrm{H}_{11} \mathrm{NO}_{2}$ & 153 & 7.35 \\
\hline 3. & 6.80 & tert-Hexadecanethiol & $\mathrm{C}_{16} \mathrm{H}_{34} \mathrm{~S}$ & 258 & 4.75 \\
\hline 4. & 8.30 & Cyclopropyl 4-methoxyphenyl ketone & $\mathrm{C}_{11} \mathrm{H}_{12} \mathrm{O}_{2}$ & 176 & 18.53 \\
\hline 5. & 10.99 & Pentanal, 5-(methylenecyclopropyl)- & $\mathrm{C}_{9} \mathrm{H}_{14} \mathrm{O}$ & 138 & 3.53 \\
\hline 6. & 13.07 & 5-Hydroxymethylfurfural & $\mathrm{C}_{6} \mathrm{H}_{6} \mathrm{O}_{3}$ & 126 & 29.21 \\
\hline 7. & 14.86 & Cyclobarbital & $\mathrm{C}_{12} \mathrm{H}_{16} \mathrm{~N}_{2} \mathrm{O}_{3}$ & 236 & 2.95 \\
\hline 8. & 16.91 & Butanoic acid, 3-oxo-, 2-propenyl ester & $\mathrm{C}_{7} \mathrm{H}_{10} \mathrm{O}_{3}$ & 142 & 1.78 \\
\hline 9. & 19.11 & Furan-2-carboxaldehyde, 5-(1-piperidyl)- & $\mathrm{C}_{10} \mathrm{H}_{13} \mathrm{NO}_{2}$ & 179 & 2.93 \\
\hline 10. & 22.58 & $\begin{array}{l}\text { 8H-Pyrano[3,4-b]pyrimido[5,4-d]furane, } \\
\text { 5,6-dihydro-4-hydrazino-6,6-dimethyl-2- } \\
\text { methylthio- }\end{array}$ & $\mathrm{C}_{12} \mathrm{H}_{16} \mathrm{~N}_{4} \mathrm{O}_{2} \mathrm{~S}$ & 280 & 6.01 \\
\hline 11. & 23.48 & $\begin{array}{l}\text { Ethanone, 1-(1a,2,3,5,6a,6b-hexahydro- } \\
\text { 3,3,6a-trimethyloxireno[g]benzofuran-5- } \\
\text { yl)- }\end{array}$ & $\mathrm{C}_{13} \mathrm{H}_{18} \mathrm{O}_{3}$ & 222 & 1.43 \\
\hline 12. & 24.52 & $\begin{array}{l}\text { Furfurole, } \\
\text { hydroxybenzoylhydrazone }\end{array}$ & $\mathrm{C}_{13} \mathrm{H}_{12} \mathrm{~N}_{2} \mathrm{O}_{3}$ & 244 & 4.79 \\
\hline 13. & 25.88 & Octadecane, 3-ethyl-5-(2-ethylbutyl)- & $\mathrm{C}_{26} \mathrm{H}_{54}$ & 366 & 1.29 \\
\hline 14. & 28.59 & $\begin{array}{ll}\text { Spirost-8-en-11-one, } & \text { 3-hydroxy-, } \\
(3 \beta, 5 \alpha, 14 \beta, 20 \beta, 22 \beta, 25 \mathrm{R})- & \\
\end{array}$ & $\mathrm{C}_{27} \mathrm{H}_{40} \mathrm{O}_{4}$ & 428 & 0.29 \\
\hline 15. & 30.80 & Isopropyl linoleate & $\mathrm{C}_{21} \mathrm{H}_{38} \mathrm{O}_{2}$ & 322 & 0.52 \\
\hline 16. & 31.48 & $\begin{array}{lr}\text { Androstane-11,17-dione, } & 3- \\
\text { [(trimethylsilyl)oxy]-, } & 17-[\mathrm{O}- \\
\text { (phenylmethyl)oxime], }(3 \alpha, 5 \alpha)- & \\
\end{array}$ & $\mathrm{C}_{29} \mathrm{H}_{43} \mathrm{NO}_{3} \mathrm{Si}$ & 481 & 0.17 \\
\hline 17. & 35.09 & $\begin{array}{l}\text { 1,8-Dioxa-5-thiaoctane, } \\
\text { borabicyclo[3.3.1]non-9-yl)-3-(9- } \\
\text { borabicyclo[3.3.1]non-9-yloxy)-1-phenyl- }\end{array}$ & $\mathrm{C}_{27} \mathrm{H}_{42} \mathrm{~B}_{2} \mathrm{O}_{3} \mathrm{~S}$ & 468 & 0.16 \\
\hline 18. & 36.60 & $\begin{array}{l}\begin{array}{l}9,12,15- \\
\text { bis[(trimethylsilyl)oxy]propyl }\end{array} \\
(\mathrm{Z}, \mathrm{Z}, \mathrm{Z})-\end{array}$ & $\mathrm{C}_{27} \mathrm{H}_{52} \mathrm{O}_{4}$ & 496 & 6.29 \\
\hline 19. & 38.38 & $\begin{array}{l}\text { Androst-5-en-17-one, } \\
\text { (phenylmethyl)oxime, (3ß)- }\end{array}$ & $\mathrm{C}_{29} \mathrm{H}_{43} \mathrm{NO}_{2}$ & 465 & 1.67 \\
\hline
\end{tabular}

*RT -Retention Time

Mathur et al., (2011) has been reported to be hypocholesterolemic, nematicide, pesticide, antiandrogenic, hemolytic, 5-alpha reductase inhibitor activities. n- Hexadecanoic acid is a significantly important phytochemical compound, also found to be present in the extract and is known to have been reported to be antimicrobial and antioxidant (Oskoueian et al., 2011). 
Oleic has been reported to be effective in treatment of skin papillomas. 2benzenedicarboxylic acid and Palmitic acid are two other biologically active compounds, which possess anti-tumor and anticancerous properties. Isosorbide dinitrate has been reported to be utilized in vasodilator therapy of heart failure. (Banerjee et al., 1991).

Stearic acid is involved in lowering of plasma cholesterol levels. 1, 2-Benzenediol possesses carcinogenic activity (Klingler and Ebertz, 2005). Levulinic acid is a Precursor to pharmaceuticals, Melamine possesses trypanocidal activity, 1, 2, 3-Propanetriol, 1acetate is anti-dipogenic in nature (Stewart et al., 2004).

From the results obtained from GC-MS analysis of raw juice of sugarcane and treated juice, it can be concluded that besides being sugar (carbon) source, the plant also exhibits several biological and pharmaceutical properties which provide an insight to the medical value of sugarcane plant which can be further evaluated to optimize how the plant may be utilized to explore its medicinal potential. Further treated sugarcane juice can be extended the shelf life of sugarcane juice in refrigerator condition.

\section{Acknowledgement}

The authors are sincerely thankful to Indian Institute of Food Processing Technology, Ministry of Food Processing Industries, Govt. of India, Department of Food Safety and Quality Testing, Thanjavur for instrumentation support to carry out research work.

\section{References}

Ashish Khare, Dr. Apoorva Behari Lal, Anurag Singh and Amit Pratap Singh (2012) Shelf life enhancement of sugarcane juice. Croatian Journal of Food Technology, Biotechnology and Nutrition 7 (3-4), 179-183

Banerjee A and Banerjee AK: Effect of the fungicides tridemorph and vinclozolin on soil microorganism and nitrogen metabolism. Folia Microbial., 1991; 36(6): 567-571.

Banerji R, Madan V.K., Misra S. R. (1997), Preservation of sugarcane juice, Indian sugar, 47(3), 195-200.

Iacopini P, Baldi M, Storchi L, Sebastiani L (2008).Catechin, epicatechin, quercetin, rutin and resveratrol in red grape: Content, in vitro antioxidant activity and interactions. J. Food Compost. Anal. 21:589- 598

Kadam US, Ghosh SB, Strayo D, SuprasannaP, Devasagayam TPA, Bapat VA (2008). Antioxidant activity in sugarcane juice and its protective role against radiation induced DNA damage. Food Chem. 106 (3):11541160.

Kim AR, Zou Y, Kim HS, Choi JS, Chang GY, KimYJ and Chung HY: Selective peroxynitrite scavenging activity of 3methyl-1, 2-cyclopentanedione from coffee extract. Journal of Pharmacy and Pharmacology 2010; 54(10): 13851392.

Klingler FD and Ebertz W: Oxocarboxylic Acid in Ullmann's Encyclopedia of industrial chemistry. Wiley- $\mathrm{VCH}$, Weinheim. 2005

Krishnakumar T. and Devadas C.T. (2006), Microbiological changes during storage of sugarcane juice in different packing materials, Beverage Food World 42(4), 82-83.

Manish Dev Sharma, Indra Rautela, Nishesh Sharma1, Manoj Gahlot and Eapen P Koshy (2015) GC-MS analysis of phytocomponents in juice sample of Indian cane: Saccharum barberi. International Journal of Pharmaceutical 
Sciences and Research. Vol. 6(12): 5147-5153.

Mathur $\mathrm{M}$ and Kamal R: Studies on trigonelline from Moringa oleifera and its in vitro regulation by feeding precursor in cell cultures. Brazilian Journal of Pharmacognosy 2011; $3(2): 123-132$

Oskoueian E, Abdullah N, Ahmad S, Saad WZ, Omar AR and Ho YW: Bioactive compound and biological activities of Jatropha curcas L. kernel meal Extarct. International Journal of Molecular Sciences 2011; 12: 59555970.

Phanikumar H.K (2011), Sugarcane juice powder by spray drying technique, Science Tech Enterpreneur, National
Research Development Corporation (An Enterprise of DSIR, Min. of S \& $\mathrm{T}$, Government of India), Malleswaram, Bengaluru.

Stewart ML, Bueno GJ, Baliani A, Klenke B, Brun R, Brock JM. Gilbert IH and Barrett MP: Trypanocidal Activity of Melamine-Based Nitroheterocycles. American Society for Microbiology 2004; 10: 724-732.

Suresh-Kumar CA, Varadharajan R, Muthumani P, Meera R, Devi P, Kameswari B (2010). Psychopharmacological studies on the stem of Saccharum spontaneum. Int. J. Pharm. Tech. Res. 2(1):319-324.

\section{How to cite this article:}

Rajendran, P., R. Bharathidasan and Sureshkumar, K. 2017. GC-MS Analysis of PhytoComponents in Raw and Treated Sugarcane Juice. Int.J.Curr.Microbiol.App.Sci. 6(7): 51-61. doi: https://doi.org/10.20546/ijcmas.2017.607.007 